\title{
Pollination of Soybean (Glycine max L. Merril) by Honeybees (Apis mellifera L.)
}

\author{
Wainer César Chiari ${ }^{1}$, Vagner de Alencar Arnaut de Toledo ${ }^{1 *}$, Maria Claudia Colla \\ Ruvolo-Takasusuki ${ }^{2}$, Arildo José Braz de Oliveira ${ }^{3}$, Eduardo Shiguero Sakaguti ${ }^{1}$, Valeria \\ Maria Attencia ${ }^{1}$, Fabiana Martins Costa $^{1}$ and Marina Hitomi Mitsui ${ }^{1}$ \\ ${ }^{1}$ Departamento de Zootecnia; vaatoledo@uem.br; ${ }^{2}$ Departamento de Biologia Celular e Genética; ${ }^{3}$ Departamento \\ de Farmácia; Universidade Estadual de Maringá - UEM; Av. Colombo, 5790; 87.020-900; Maringá - PR - Brazil
}

\begin{abstract}
This experiment was carried out to evaluate the effect of the honeybee pollination in the production and quality of soybean seeds (Glycine max L. Merril). Seed production was higher $(P=0.0001)$ in covered areas with honeybee colonies (50.64\%) and uncovered areas $(57.73 \%)$ than in covered areas without honeybee colonies. It could be concluded that honeybees were responsible for $95.5 \%$ of the pollination accomplished by insects. The pod number in covered treatment with honeybees was $61.38 \%$ higher $(P=0.0002)$ than in the covered treatment without honeybees. The average weight of 100 seeds was larger $(P=0.0001)$ in the area covered without honeybees, and reached $17.8 \mathrm{~g}$. The medium content of crude protein in grains was $36.7 \%$ and the average oil content was $20.2 \%$. The germination test did not show differences $(P>0.05)$ among the seeds in different treatments. It was concluded that the honeybee pollination in the soybean increased the seeds production.
\end{abstract}

Key words: Apis mellifera, soybean, Glycine max, honeybees, pollination, seed production

\section{INTRODUCTION}

The soybean (Glycine max L. Merril) is one of the most cultivated grains in the entire world. In the United States the crop had an estimated value of US\$ 16,490,700,000.00 in 1998 (Morse and Calderone, 2000). About $10 \%$ of this production was by pollination made by insects and $50 \%$ by Apis mellifera $\mathrm{L}$. The estimated benefit was US\$ $824,500,000.00$ to the agriculture. Soybean flower structure ensures to the honeybees the harvesting, favoring the pollen transference and the production increasing (Erickson and Garment, 1979). Other authors like Morse and Carter (1937), Rubis (1970) considered the soybean like autogamic.
Self-pollination can occur in some plants, without the necessity of the action of pollinator, while other needs to receive pollen of other plants of the same species. However, auto-fertility species can benefit from cross-pollination, ensuring higher productions (Crane and Walker, 1983). Paiva (2000) observed in experiments with sunflowers (Helianthus annuus) increase in the seeds production $(78.37 \%)$ when compared with plants without access to the pollination made by insects. Juliano (1976) reported in the pollinated soybean, increase the pods number $(37.95 \%)$, and the pods average weight $(39.85 \%)$ related to the non pollinated (control), to the Santa Rosa variety. According to Issa et al. (1984), the honeybee is an efficient pollinator for some soybean varieties

\footnotetext{
Author for correspondence
} 
which resulted an increase in the seed production (95\%) and $81 \%$ to the varieties IAC-5115 and IAC-3, respectively under the same conditions. The soybean plants, v. IAC-114 showed increase in the pods number $(58.58 \%)$ and seeds $(82.31 \%)$ when visited by the honeybees (Moreti et al., 1998). Erickson (1975), Abrams et al. (1978) and Erickson et al. (1978), working with G. $\max$, found an increase of 5 to $20 \%$ in the soybean production with the colony collocation of $A$. mellifera in experiments with cages. Pollination studies of legume forages showed that in the culture of perennial soybean $(G$. wightii) there was an increase in the pod production $(55.8 \%)$ and seeds $(44.7 \%)$ in the presence of A. mellifera (Nogueira and Pereira, 1983; Nogueira-Couto et al., 1998). This study was carried out to evaluate the production and quality of seeds obtained in different pollination systems in soybean (Glycine max Merril) culture, variety BRS-133, and lot 710B in Maringá-Paraná, Brazil.

\section{MATERIAL AND METHODS}

The experiment was carried out in a 15 ha field of soybeans variety BRS-133. Pollination cages were made of nylon screen of $2 \times 2 \mathrm{~mm}$, supported by pipes of $1 / 4$ of inch in PVC, forming cages of four meters width, six meters length and two meters height in the highest part, on an area of $24 \mathrm{~m}^{2}$ (Fig. 1).

The soybean crop was harvested after 122 days and was monitored with particular attention during the blooming. The treatments were: (a)- uncovered areas, $24 \mathrm{~m}^{2}$ each, demarcated with colored ribbon; (b)- covered area with honeybees, one colony of five combs and (c)- covered area without honeybees. Each treatment replicated five times. The areas chosen for study were demarcated at random in the soybean field and the cages were put immediately before the beginning of blossom and when the last blossom closed.

The seed production was obtained through the clean, classification and weight of grains collected in the central area of each plot $\left(12 \mathrm{~m}^{2}\right)$ in all treatments. Samples were collected at random from 35 soybean plants in each plot to obtain the average of number of pods and seeds in each pod in each harvested plant of the three treatments. The evaluation of average weight of seeds was made through weights of 100 seeds (five replications). The germination test of the seeds was made as described in Ministério da Agricultura (Brasil, 1986). The crude protein analysis and ether extract of the soybean grains were made according to the methods of Silva (1990).

The data were statistically analyzed according to completely randomized design. After analysis of variance, averages were compared by Tukey's test (Pimentel Gomes, 1990), using the GLM procedure of SAS (Sas Institute, 1998).

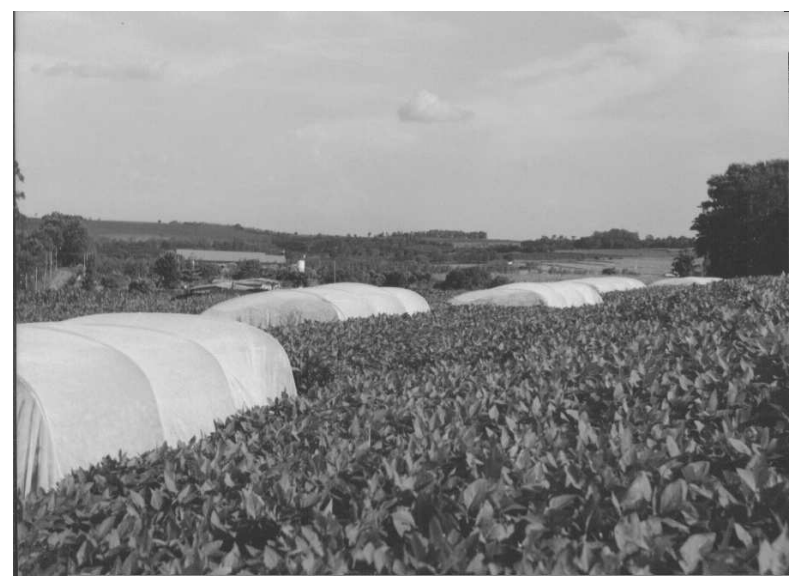

Figure 1 - Pollination cage model used in the experiment with dimensions $4 \mathrm{~m} \times 6 \mathrm{~m}$.

\section{RESULTS}

Table 1 shows production in the experimental area (production/plant $(\mathrm{g})$, production/ha $(\mathrm{kg})$ and sacs/ha in different treatments). There was no difference $(\mathrm{P}>0.05)$ among the uncovered area and covered area with honeybees. However, in $(\mathrm{P}=0.0001)$ covered area without honeybees. Estimated production was 2,394.58 kg/ha or 39.91 sacs/ha. The production in covered area with honeybees was $50.64 \%$ higher than in covered area without honeybees or, 20.21 sacs/ha more.

In the opened area, freely visited by insects, the increase in the seed production related to the treatment covered without honeybees was $57.73 \%$, or $23.04 \mathrm{sacs} / \mathrm{ha}$. The pods and seeds number in uncovered area, covered with honeybees and covered without honeybees, presented differences between themselves $(\mathrm{P}=0.0001)$ (Table 2).

The pod number in covered area with honeybees was $61.38 \%$ higher $(\mathrm{P}=0.0002)$ than in the covered area without honeybees, and this was $90.71 \%$ smaller than observed in free treatment. In areas where A. mellifera was responsible for the pollination there was an increase of $58.86 \%$ in the 
number of seeds in comparison to the treatment in that pollination was not allowed. It could be observed from Table 3 that the average weight of 100 seeds did not differ between the treatment uncovered and covered with honeybees $(\mathrm{P}>0.05)$, however, these treatments were inferior to the covered without honeybees $(\mathrm{P}=0.0001)$.

The results of the seeds germination test in three treatments are presented in Table 4. The germination percentage did not differ $(\mathrm{P}>0.05)$ between the treatments. Meanwhile, the normal plant number was superior $(\mathrm{P}=0.0001)$ in uncovered area, in relation to the treatments covered with honeybees and covered without honeybees.

Table 5 shows the results of bromatological analysis of seeds sampled in three treatments. There was no difference $(\mathrm{P}>0.05)$ between the treatments. Crude protein content and ether extract were in the normal rate to the soybean grain. The average content of crude protein in the seeds was $36.69 \pm$ $1.08 \%$ and of ether extracts $20.24 \pm 1.12 \%$.

Table 1 - F values with respective probability $(\mathrm{P})$, coefficient of variation $(\mathrm{CV} \%)$, production $(\mathrm{g})$ of $12 \mathrm{~m}^{2}$, production (g/plant), production in $\mathrm{kg} / \mathrm{ha}$ and production of sacs/ha of soybean Glycine max, variety BRS-113

\begin{tabular}{|c|c|c|c|c|}
\hline Variation source & \begin{tabular}{|c|} 
Production in \\
$12 \mathrm{~m}^{2}(\mathrm{~g})$
\end{tabular} & $\begin{array}{c}\text { Production/ha } \\
\text { (kg) }\end{array}$ & & $\begin{array}{l}\text { Production } \\
\text { (sacs/ha) }\end{array}$ \\
\hline Treatments & $100.05 \quad \mathrm{P}=0.0001$ & $100.05 \quad \mathrm{P}=0.0001$ & 100.05 & $\mathrm{P}=0.0001$ \\
\hline $\mathrm{CV} \%$ & 3.45 & 3.45 & 3.45 & \\
\hline Uncovered area & 4532.40 a $( \pm 169.71)$ & 3777.00 a $( \pm 141.43)$ & 62.95 & a $( \pm 2.37)$ \\
\hline $\begin{array}{l}\text { Covered area with } \\
\text { honeybees }\end{array}$ & 4328.60 a $( \pm 133.40)$ & 3607.17 a $( \pm 111.17)$ & 60.12 & a $( \pm 1.85)$ \\
\hline $\begin{array}{l}\text { Covered area without } \\
\text { honeybees }\end{array}$ & $2873.50 \quad b( \pm 80.00)$ & $2394.58 \quad b( \pm 65.00)$ & 39.91 & $\mathrm{~b}( \pm 2.00)$ \\
\hline
\end{tabular}

\section{DISCUSSION}

There are a few studies on pollination in soybean. For example Erickson (1975, 1984) found an increase from $5-20 \%$ and Issa et al. (1984) from 9-81\% for two varieties IAC-5115 and IAC-3, respectively.

The results found in own experiment corresponded to a reduction of $4.5 \%$ in the area with free visits in relation to the covered area with honeybees. These results suggested that the pollination made by insects, in particular $A$. mellifera, was responsible for the increase in the productivity.

In the treatments with pollination made by honeybees $A$. mellifera, the average increase in the pods number was $61.38 \%$ and of seeds $58.86 \%$. These results are similar to these found by Moreti et al. (1998), 58.58\% in the pods number and $82.31 \%$ in the seeds number and by Nogueira-Couto and Pereira (1983) and
Nogueira-Couto et al. (1998), 55.8\% in pod number. But these results are superior to the ones found by Erickson (1975) and Erickson et al. (1978) that obtained income between 5 and $20 \%$ in the seeds number and Juliano (1976) that found in variety Santa Rosa an increase of $37.95 \%$ in the pod numbers. Increasing in the seeds number in covered area with honeybees and uncovered area in relation to the place setting without honeybees were not followed by the increase in average weight of the seeds. 
Table 2 - F values with the respective probability $(\mathrm{P})$, coefficient of variation $(\mathrm{CV} \%)$ of average number of pods and seeds counted from samples of plants of soybean Glycine max, variety BRS-133

\begin{tabular}{|c|c|c|}
\hline Variation source & Number of pods & Number of seeds \\
\hline \multirow[t]{2}{*}{ Treatments } & 9.98 & 9.58 \\
\hline & $\mathrm{P}=0.0002$ & $P=0.0002$ \\
\hline $\mathrm{CV} \%$ & 30.06 & 30.40 \\
\hline \multirow[t]{2}{*}{ Uncovered area } & $49.87 \mathrm{a}^{*}$ & $111.01 \mathrm{a}$ \\
\hline & $( \pm 13.00)$ & $( \pm 28.71)$ \\
\hline \multirow[t]{2}{*}{ Covered with honeybees } & $40.83 \quad b$ & $90.71 \quad b$ \\
\hline & $( \pm 13.88)$ & $( \pm 31.90)$ \\
\hline \multirow[t]{2}{*}{ Covered without honeybees } & $25.30 \quad \mathrm{c}$ & $57.10 \quad \mathrm{c}$ \\
\hline & $( \pm 7.69)$ & $( \pm 15.74)$ \\
\hline
\end{tabular}

Averages followed by different small letters, in the same column, are different by Tukey's test $(\mathrm{P}<0.05)$

Table 3 - F values with respective probability (P), coefficient of variation (CV\%) and weight of 100 seeds in $(\mathrm{g})$ of soybean Glycine max, variety BRS-133

\begin{tabular}{lll}
\multicolumn{1}{c}{ Variation source } & \multicolumn{1}{c}{ Weight of 100 seeds (g) } \\
\hline Treatments & 33.65 & $\mathrm{P}=0.0001$ \\
CV\% & 5.27 & \\
Uncovered area & 15.26 & $\mathrm{~b}( \pm 0.95)$ \\
Covered with honeybees & 15.37 & $\mathrm{~b}( \pm 0.64)$ \\
Covered without honeybees & 17.80 & $\mathrm{a}( \pm 0.91)$ \\
\hline
\end{tabular}

Averages followed by different small letters, in the same column, are different by Tukey's test $(\mathrm{P}<0.05)$

Table 4 - F values with the respective probability $(\mathrm{P})$, coefficient of variation $(\mathrm{CV} \%)$ and the percentage of normal plants, abnormal plants, dead and the percentage of soybean Glycine max seeds germination, BRS-113 variety

\begin{tabular}{llll}
\hline \multicolumn{1}{c}{ Variation source } & \multicolumn{1}{c}{ Normal (\%) } & \multicolumn{1}{c}{ Abnormal (\%) } & \multicolumn{1}{c}{ Germination (\%) } \\
\hline Treatments & $10.25 \mathrm{P}=0.0001$ & $8.42 \quad \mathrm{P}=0.0005$ & $2.31 \mathrm{P}=0.1052$ \\
$\mathrm{CV} \%$ & 5.25 & 14.87 & 9.28 \\
Uncovered area & $0.68 \pm 0.30 \mathrm{a}^{*}$ & $0.27 \pm 0.41 \mathrm{~b}$ & $1.32 \pm 0.12$ \\
& $(39.30 \pm 2.98)^{* *}$ & $(7.10 \pm 2.09)$ & $(92.80 \pm 4.72)$ \\
Covered with & $0.64 \pm 0.40 \mathrm{~b}$ & $0.28 \pm 0.40 \mathrm{a}$ & $1.27 \pm 0.13$ \\
honeybees & $(36.13 \pm 3.90)$ & $(8.75 \pm 2.40)$ & $(89.75 \pm 6.33)$ \\
Covered without & $0.63 \pm 0.31 \mathrm{~b}$ & $0.32 \pm 0.34 \mathrm{a}$ & $1.27 \pm 0.09$ \\
honeybees & $(35.13 \pm 3.73)$ & $(10.13 \pm 2.10)$ & $(90.50 \pm 4.75)$ \\
\hline
\end{tabular}

* Mean followed by different small letters, in the same column, are different by Tukey's test $(\mathrm{P}<0.05)$

** Numbers between parenthesis show the not transformed means and the standard error

Table 5 - F values with respective probability $(\mathrm{P})$, coefficient of variation $(\mathrm{CV} \%)$ and the percentage of protein and ether extract in the soybean seeds Glycine max, variety BRS-133

\begin{tabular}{lll}
\hline \multicolumn{1}{c}{ Variation source } & \multicolumn{1}{c}{ Protein } & \multicolumn{1}{c}{ Etherl extract } \\
\hline Treatments & $0.73 \mathrm{P}=0.5124$ & $0.13 \mathrm{P}=0.8828$ \\
$\mathrm{CV} \%$ & 3.08 & 6.09 \\
Uncovered area & $36.24( \pm 1.30)$ & $20.22 \quad( \pm 1.70)$ \\
Covered with honeybees & $37.01( \pm 0.93)$ & $20.14 \quad( \pm 0.40)$ \\
Covered without honeybees & $37.27( \pm 0.89)$ & $20.82 \quad( \pm 0.86)$ \\
\hline
\end{tabular}


These seeds were $13.96 \%$ heavier in covered area without honeybees, when compared with other treatments. These results disagree with Levin (1983) and Malerbo-Souza (1996) that reported seeds and fruits larger and heavier, with more sweetened flavor, when resulting of crosspollination made by insects, but they are in agreement to Fávaro and Nogueira-Couto (2000) that found an increase of $15.45 \%$ in the medium weight of the seeds in the treatment in which the plants did not receive visitation of insects.

The largest weight found in seeds originated by auto-pollination could be consequence of a larger amount of nutrients available for their development. Like this, the total weight of a high number of smaller seeds was superior to the total weight of bigger seeds in small number. This fact suggested that could be an excess of nutrients in the plants of the covered area without honeybees, as because of the lack of pollination and decrease in the fertilization, it would not be possible to use these recourses that result in low productivity.

There are soybean varieties that can be benefited by the insects through the pollination (Erickson,1975, 1984; Issa et al., 1984; Moreti et al., 1998), increasing the productivity.

The A. mellifera honeybees were efficient to accomplish the cross-pollination works in the soybean flower and their uses in the agriculture bring considerable gain. The utilization of $A$. mellifera as pollinators in the soybean culture cultivated in big areas is not common in Brazil, but the beehive demand is big.

\section{ACKNOWLEDGEMENTS}

We are grateful to Conselho Nacional de Desenvolvimento Científico e Tecnológico (CNPq) process no. 479868/01-8 for financial support and Coordenação de Aperfeiçoamento Pessoal de Nível Superior (CAPES) for the grant of scholarships.

\section{RESUMO}

Este experimento teve como objetivo avaliar a polinização realizada pelas abelhas na produção e qualidade das sementes da soja (Glycine max L. Merril) na região de Maringá-PR. Os tratamentos constituíram de áreas demarcadas de livre visitação por insetos, áreas cobertas por gaiolas com uma colônia de abelhas (Apis mellifera) e plantas também cobertas por gaiolas que impediam a visitação por insetos. Todas as áreas possuíam $24 \mathrm{~m}^{2}$ (4 m x $6 \mathrm{~m}$ ), com cinco repetições cada. A produção de sementes foi maior $(\mathrm{P}=0,0001)$ nas áreas cobertas com abelhas e de livre visitação com um incremento na produtividade de $50,64 \%$ e $57,73 \%$, respectivamente, em relação à área coberta sem abelhas. Pode-se considerar que as abelhas $A$. mellifera foram responsáveis por $95,5 \%$ da polinização realizada pelos insetos no tratamento livre. $\mathrm{O}$ número de vagens no tratamento coberto com abelhas foi $61,38 \%$ maior $(\mathrm{P}=0,0002)$ do que no coberto sem abelhas. Onde as abelhas $A$. mellifera foram responsáveis pela polinização cruzada, houve um aumento de $58,86 \%$ no número de sementes em relação ao tratamento onde não foi permitida a polinização realizada por insetos. Entretanto, o peso médio de 100 sementes foi maior $(\mathrm{P}=0,0001)$ na área coberta sem abelhas, atingiu um peso médio de $17,80 \mathrm{~g}$, mostrando que plantas com menor produção formaram sementes maiores. No tratamento livre, o peso médio de 100 sementes foi de $15,26 \mathrm{~g}$ e no coberto com abelhas foi de $15,37 \mathrm{~g}$. O teor médio de proteína bruta no grão foi de $36,69 \%$ e a média do teor de óleo foi de $20,24 \%$. O teste de germinação não mostrou diferenças entre as sementes nos diferentes tratamentos. Pode-se concluir que as abelhas $A$. mellifera foram eficientes no trabalho de polinização na soja, proporcionando um aumento considerável na produção de grãos e estes resultados reforçam a necessidade do uso das abelhas A. mellifera para elevar a produtividade da soja.

\section{REFERENCES}

Abrams, R. I.; Edwards, C. R. and Harris, T. (1978), Yields and cross-pollination of soybeans as affected by honeybees and alfalfa leaf cutting bees. American Bee Journal, 118, 555-556, 558.

Brasil. (1986), Ministério da Agricultura. Regras para análise de sementes. Brasília : DNPV.

Crane, E. and Walker, P. (1983), Pollination of tropical and subtropical crops by bees. In: Crane, E., Walker, P. The impact of pest management on bees and pollination. Cardiff : IBRA. pp. 5-21.

Erickson, E. H. (1975), Effect of honey bees on yield of three soybean cultivars. Crop Science, 15 : (1), 84-86. 
Erickson, E. H. (1984), Soybean pollination and honey production a research progress report. American Bee Journal, 124, 775-779.

Erickson, E. H. and Garment, M. B. (1979), Soya-bean flowers: nectary ultra structure, nectar guides, and orientation on the flower by foraging honeybees. Journal of Apicultural Research, 18 : (1), 1-11.

Erickson, E. H.; Berger, G. S. and Shannon, J. G. et al. (1978), Honey bee pollination increases soybean yields in the Mississippi Delta Region of Arkansas and Missouri. Journal of Economic Entomology, 71, 601-603.

Fávero, A. C. and Nogueira-Couto, R. H. (2000), Polinização em soja. In: Congresso Nacional de Apicultura, 13., Florianópolis - SC. Anais... Florianópolis - SC.

Issa, M. R. C.; Velocci, M. E. P. and Gonçalves, L. S. et al. (1984), Ensaio de polinização da soja (Glycine max) por abelhas (Apis mellifera). In: Congresso Brasileiro de Apicultura, 5.; Congresso IberoAmericano de Apicultura, 3., Viçosa - MG. Anais... Viçosa - MG.

Juliano, J. C. (1976), Polinização entomófila da soja. In: Congresso Brasileiro de Apicultura, 4., Curitiba - PR. Anais... Curitiba - PR.

Levin, M. D. (1983), Value of bee pollination to U.S. agriculture. Bulletin of the Entomological Society of America, 29, 59-51.

Malerbo-Souza, D. T. (1996), Efeitos de atrativos e repelentes sobre o comportamento forrageiro de abelhas, Apis mellifera. Tese (Doutorado) - Faculdade de Ciências Agrárias e Veterinária de Jaboticabal, Jaboticabal - SP, Brasil.

Moreti, A. C. C. C.; Silva, E. C. A. and Alves, M. L. T. M. F. et al. (1998), Observações sobre a polinização entomófila da cultura da soja (Glycine max Merril). Boletim da Indústria Animal, 55 : (1), 91-94.

Morse, R. A. and Cartter, J. L. (1937), Improvement in soybeans. Yb. U.S. Dep. Agric., 1154-1159.

Morse, R. A. and Calderone, N. W. (2000), The value of honey bees as pollinators of U.S. crops in 2000. Bee Culture, 132 : (3), 1-15.
Nogueira-Couto, R. H. and Pereira, J. M. S. (1983), Polinização entomófila em Glycine wightii (soja perene). In: Reunião da SBPC, 35., Belém - PA. Anais... Belém - PA.

Nogueira-Couto, R. H.; Pereira, J. M. S. and De Jong, D. (1998), Pollination of Glycine wightii, a perennial soybean, by Africanized honey bees. Journal of Apicultural Research, 3 : (4), 289-291.

Paiva, G. J. (2000), Comparação da produção de sementes de girassol (Helianthus annuus L.) em três sistemas de polinização por abelhas. Dissertação (Mestrado), Universidade Estadual de Maringá, Maringá - PR, Brasil.

Pimentel Gomes, F. (1990), Curso de estatística experimental. Piracicaba : Nobel.

Rubis, D. D. (1970), Breeding insect pollinated crops. Arkansas Agricultural Extension Service, 127, 19-24.

SAS Institute (1998), User's guide. Carry, NC : SAS Institute.

Silva, D. J. (1990), Análise de alimentos: métodos químicos e biológicos. Viçosa-MG : UFV.

Received: August 06, 2003; Revised: December 11, 2003 ; Accepted: July 15, 2004. 